\title{
Apresentação
}

\section{Claudia Heller}

Departamento de Economia, Faculdade de Ciências e Letras de Araraquara, Universidade Estadual Paulista

O texto "Technical progress", reproduzido nessa seção, corresponde ao nono capítulo do livro The accumulation of capital, de Joan Robinson, publicado em 1956. O objetivo central deste livro - o desenvolvimento de uma teoria do investimento de longo prazo cuidando de tratar o tempo no sentido histórico - era uma meta bastante ambiciosa, pois procurava levar em conta a distribuição da renda, as várias formas possíveis de progresso técnico e as diferentes alternativas de estrutura de mercado (ou formas de concorrência). A obra traduz os resultados do War Circus ${ }^{1}$ e representa o melhor exemplo da estratégia de exposição típica de Joan Robinson: o "método das aproximações sucessivas", em que, começando com um modelo simples, vão sendo incorporadas novas variáveis ou passa-se a supor variaçôes no que antes era considerado constante.

Generalizar a Teoria Geral de Keynes para o longo prazo foi uma tarefa que Joan Robinson assumiu como essencial já na década de 1930 e com a qual nunca ficou inteiramente satisfeita. Embora a autora não se propusesse a elaborar uma teoria do progresso técnico, a relevância deste tema é facilmente identificável na própria estrutura do livro, que está organizado em torno de oito tópicos (“books”).

1 Os debates entre a autora e Nicholas Kaldor, Piero Sraffa e Richard Kahn, no War Circus, tinham como temas centrais o crescimento, a acumulação e os ciclos. Estas discussões assemelhavam-se às que ocorreram no Cambridge Circus, que no início da década de 1930 giraram em torno das ideias de John Maynard Keynes. Embora não participasse do War Circus, Roy Harrod foi outra fonte de inspiração importante para The accumulation of capital, especialmente em torno do conceito de progresso técnico neutro (conforme Joan Robinson reconhece no prefácio ao livro). 
O segundo deles aborda a acumulação no longo prazo e está dividido em três seções, as quais trazem a questão da técnica nos seus títulos. $\mathrm{O}$ nono capítulo pertence a este segundo tópico.

Há várias referências da importância que Joan Robinson atribui ao progresso técnico, tanto em trabalhos anteriores quanto em posteriores ao The accumulation of capital. Um exemplo encontra-se já na sua primeira tentativa de desenvolver uma teoria do emprego no longo prazo, destacando o duplo caráter do investimento: como componente da demanda agregada e como formação de capacidade produtiva, pois no longo prazo - por definição - o estoque de capital não é fixo.

Seu argumento básico pode ser sintetizado da forma descrita a seguir. Numa abordagem keynesiana de curto prazo, uma redução da taxa de juros tende a incentivar a criação de emprego (e elevação do produto), pois eleva o retorno esperado do investimento (em termos relativos aos juros) e, ao mesmo tempo, reduz o custo deste investimento. No entanto, no curto prazo, supõe-se que o estoque de capital não se altera, o que significa que a redução da taxa de juros reflete-se apenas na elevação da produção e do nível de emprego, reduzindo o nível de capacidade ociosa da economia. No longo prazo, além da utilização da capacidade ociosa, a redução da taxa de juros pode levar à criação de nova capacidade produtiva - novos bens de capital. Nas análises mais simplificadas, estes novos bens de capital são iguais aos antigos, mas, nas que incorporam a possibilidade do progresso técnico, é preciso considerar que os novos bens de capital podem ser substitutos de mão de obra nos setores e ramos em que são utilizados e nestes, portanto, o nível de emprego pode cair. Por outro lado, também é possível que o nível de emprego aumente devido à própria expansão do setor e ramos produtores de bens de capital e/ou de consumo. Estes efeitos contrários podem, ou não, anular-se mutuamente. Isto significa - segundo Joan Robinson - que não é possível prever os efeitos de uma redução da taxa de juros sobre o emprego de longo prazo sem que se avaliem, por um lado, a possibilidade de que haja substituição de trabalho por capital e, por outro, os efeitos da alteração do nível de emprego sobre a distribuição da renda e a propensão a consumir.

Outro exemplo da importância do tema está associado à famosa "controvérsia do capital" - um debate convencionalmente entendido como girando em torno da sua medida agregada. ${ }^{2}$ Para a autora, a medida do capital não é um problema que se apresenta apenas em termos da análise agregada, mas também e principalmente

2 Também denominada "controvérsia de Cambridge", pois envolvia economistas de Cambridge na Inglaterra e de Cambridge nos Estados Unidos (representados principalmente por Paul Samuelson e Robert Solow). 
para a teoria de longo prazo. Isto porque, assim que se supõe que os bens de capital se alteram (o caso do longo prazo), é preciso considerar que podem ocorrer todos os tipos de mudanças: quantitativas, qualitativas, de preços, de produtividade física e de lucratividade. Além disso, qualquer alteração nas proporções em que os fatores são utilizados envolve também uma reorganização dos métodos de produção.

Ao longo de sua vida, Joan Robinson procurou enfrentar esta questão usando critérios e conceitos diferentes. Assim, inicialmente, pelo critério dos efeitos do progresso técnico sobre a distribuição da renda, as inovações podiam ser poupadoras de capital, poupadoras de trabalho ou neutras. Se fosse possível elevar o nível de produção sem alterar a quantidade de fatores utilizados, tratar-se-ia do aprimoramento técnico; se a relação entre capital e trabalho aumentasse, seria intensificação de capital (ou aprofundamento de capital). Mais tarde, Joan preferiu separar o impacto das inovaçôes sobre o nível de emprego do seu impacto sobre a distribuição da renda e passou a distinguir estes critérios: para o primeiro, ela reservou a denominação intensiva/poupadora de capital/trabalho (ou neutra); e para seu efeito sobre a distribuição da renda, empregou o termo favorável/desfavorável ao capital/trabalho (ou neutra). Ela também sugeriu classificar as tecnologias segundo seu grau de mecanização, uma medida que procura incorporar aos critérios da engenharia os critérios econômicos. Em outras palavras, o critério básico de hierarquia é a produtividade, isto é, a razão entre o produto e a quantidade de fator (o produto per capita Y/L) - uma questão de "engenharia pura". A partir daí, o critério econômico considera que uma técnica que usa mais capital (do que outra) para produzir menos produto (do que esta outra) não deve constar da lista de técnicas passíveis de serem utilizadas. Este critério implica não apenas que a técnica mais mecanizada (Alfa) produz mais produto final do que a técnica Beta, com o mesmo número de trabalhadores (e Beta produz mais do que Gama, com o mesmo número de trabalhadores, etc.), mas também que o custo relativo de fazê-lo é menor, embora o custo absoluto do equipamento de Alfa possa ser maior do que o de Beta, que, por sua vez, pode ser maior do que Gama, e assim por diante.

Em The accumulation of capital e especificamente no que diz respeito à questão do progresso técnico, Joan Robinson reapresenta alguns destes conceitos, modifica outros e introduz novos termos, como técnicas superiores (e inferiores), desmecanização e alargamento de capital. As técnicas superiores são as que reduzem o período de produção (sem alterar o produto per capita) ou aumentam o produto per capita, isto é, a produtividade (sem alterar o período de produção): se a redução 
do período de produção se dá à custa da produtividade (ou vice-versa), trata-se de um aprimoramento parcial; se essa redução ocorre em conjunto com o aumento da produtividade, a técnica é mais que superior (e na situação inversa, menos que inferior). A desmecanização, por sua vez, refere-se à situação em que trabalhadores desempregados empregam-se a si mesmos com pequenas quantidades de capital (como engraxates ou mascates), ou vendendo seus serviços diretamente aos consumidores (empregados domésticos, porteiros, serviços ocasionais). Já o alargamento de capital diz respeito à ampliação da oferta de capital para uma mão de obra crescente, independentemente da razão capital/trabalho (isto é, independentemente do aprofundamento de capital). Em trabalhos posteriores, a autora ainda definiu outros conceitos, como o de inovações viesadas (não neutras), subclassificadas em diretamente viesadas e indiretamente viesadas segundo o impacto que causam nos setores usuários dos bens de capital que incorporam estas inovações, ou o de inovação criadora de capital, que corresponde à capacidade de produzir um volume maior de produto sem alterar o uso de fatores, além de custar menos, ou custando mais, ter vida útil mais longa. ${ }^{3}$

No texto reproduzido neste número da Revista Brasileira de Inovação, o conceito de progresso técnico não está definido de acordo com os critérios descritos nos parágrafos anteriores desta introdução, sendo utilizado de forma mais frouxa, introdutória, o que permite à autora tratar de vários aspectos da questão, que não suportariam um rigor analítico excessivo. Destacam-se, a seguir, os mais importantes.

A suposição, reconhecidamente simplificadora, é que a cada "estado de conhecimento técnico" corresponde um único método de produção para cada tipo de bem (de consumo e/ou de capital). Isso elimina a possibilidade de discutir critérios de escolha de técnicas alternativas e reduz a decisão empresarial à adoção ou não de melhorias nos métodos de produção. Esta forma de abordar o problema possibilita à autora tratar da concorrência, que é o mecanismo pelo qual as inovações se difundem. Os empresários progressistas são os primeiros a criar e/ou adotar as inovaçóes e usufruem da situação de first-comers (o termo não é dela): podem manter o preço (e aumentar a margem de lucro); podem reduzir o preço (e expandir seu mercado); ou uma combinação de ambos. O lucro extraordinário por eles obtido pode ser ameaçado pelos demais empresários, que também adotam inovações sempre que se

3 Para um detalhamento destes conceitos e critérios, bem como outras referências bibliográficas da obra da autora sobre progresso técnico, ver HELLER, C. Technical progress in Joan Robinson's view - an attempt at systematisation and formalisation. Review of Political Economy, v. 15, p. 521-544, 2003. Há uma versão anterior em português: HELLER, C. Progresso técnico segundo Joan Robinson: uma tentativa de sistematização e formalização. Recitec. Recife, v. 2, n. 3, p. 272-303, 1998. Disponível em: <http://www.fundaj.gov.br/rtec/art/art-013r.html>. 
sentirem ameaçados e desde que o sistema de patentes o permita. Joan Robinson tem uma concepção bastante realista do sistema de patentes, que considera paradoxal, enraizado numa contradição: o sistema de patenteamento visa evitar a difusão das inovaçôes patenteadas para preservar a rentabilidade da empresa inovadora (e proprietária da patente); isso, por um lado, incentiva o surgimento de inovaçóes, mas, por outro, desestimula sua difusão - e em muitos casos, na sua opinião, limita desnecessariamente o progresso. ${ }^{4}$

$\mathrm{O}$ tratamento dado à relação entre o aumento da produtividade e o crescimento da capacidade produtiva e de seus efeitos sobre os salários nominais e sobre os preços (e portanto sobre os salários reais), bem como sobre o nível de emprego, é outro aspecto a ser destacado. É nesta seção que a autora faz uma crítica sutil à concepção de equilíbrio (ou estabilidade), ao afirmar que "basta estabelecer as condições necessárias para a estabilidade [do sistema] para que se perceba quão precária é a sua preservação sob as regras de jogo capitalistas" (p. 89). Ela menciona quatro fatores desestabilizadores: alteração inesperada do ritmo do progresso técnico; interrupção do mecanismo competitivo; ritmo de acumulação incompatível com a taxa de crescimento da produtividade; e a não difusão do progresso técnico pelo sistema (temas das seçôes subsequentes do capítulo 9).

Outro elemento que vale a pena mencionar aparece na discussão dos efeitos de diferentes taxas de acumulação e de progresso técnico, em termos agregados, que a autora elabora comparando duas economias fictícias (Alfa e Beta), iguais em tudo exceto pelo ritmo do investimento e da introdução de inovações. O tratamento tem aspectos de path-dependence, já que ela explicita que os resultados de cada situação dependem da história pregressa de cada economia. No mesmo sentido, Robinson também discute desequilíbrios setoriais, igualmente abordados por meio de uma comparação entre duas economias (Alfa e Beta), iguais em tudo exceto pelo fato de que em uma as inovaçóes aumentam a produtividade no setor de bens de capital e, em outra, no setor de bens de consumo. Os dois casos podem ser vistos como uma abordagem ainda incompleta, mas inspiradora para tratar do desenvolvimento e do subdesenvolvimento.

Joan Robinson também considera os esforços de propaganda e os custos de venda, bem como a possível preferência dos empresários pela redução das margens de lucro em vez da alteração da política de preços, aspectos de uma estrutura de

4 Joan Robinson atuou no Swan Committee of Patents, criado pelo governo britânico em 1944 para rever a lei de patentes. A este respeito, ver HELLER, C. Oligopólio e progresso técnico no pensamento de Joan Robinson. São Paulo: Hucitec/Fapesp, 2000, especialmente as páginas 381-392. 
mercado de caráter oligopolista, que eventualmente resulta do enfraquecimento da concorrência via preços, em função justamente do progresso técnico.

Embora neste capítulo as tecnologias sejam "dadas", ela reconhece que a "taxa de progresso não é um fenômeno natural que cai do céu como uma chuva suave" (p. 96) e discute, ainda que precariamente (neste capítulo), os fatores determinantes do surgimento de descobertas e da difusão das inovações. Trata também do chamado "desemprego tecnológico", entendido como a situação em que o aumento da produtividade reduz o nível de emprego - mas considera que este fenômeno equivale à situação em que a taxa de acumulação é inferior à taxa de crescimento da população e, portanto, pode ser combatido com políticas econômicas adequadas.

Por último, vale mencionar sua definição de "idade de ouro" - "um estado mítico improvável de ocorrer numa economia real" (p. 99) -, um conceito que tem finalidades analíticas semelhantes ao do equilíbrio estável: serve fundamentalmente para identificar a precariedade das condições de funcionamento ideal de uma economia capitalista. Variações destas condições dão origem a outras "idades" (de platina, de bronze, etc.) - adjetivadas na literatura como "a metalurgia de Joan Robinson".

Finalizando, a forma não muito rigorosa como o progresso técnico é tratado neste capítulo é compatível com avaliação da autora sobre as dificuldades de abordar este tema. Em uma passagem de "Notes on the economics of technical progress", 5 por exemplo, ela alertava:

É difícil discutir progresso técnico numa linguagem precisa. Não temos uma unidade definida para medir as quantidades em questão. As mercadorias têm suas características alteradas, os bens de produção sua forma, o trabalho a produtividade, e o dinheiro seu poder de compra. Ainda assim, o problema não é metafísico. Homens de negócios reais fazem inovaçôes reais para reduzir custos reais, e disso decorrem efeitos reais. O escrúpulo medroso de se elaborar definiçôes muito precisas não deve evitar que tentemos analisá-las. Parece melhor criar uma trilha em direção ao problema fazendo simplificações drásticas, e depois adaptar o argumento aos casos complexos o melhor que pudermos. (p. 82).

Dez anos mais tarde, em "A model of technical progress"6 (um ensaio reconhecidamente mais formal, com o qual esperava esclarecer alguns pontos obscuros do livro The Accumulation of (apital), Robinson voltaria ao mesmo tema:

5 ROBINSON, J. Notes on the economics of technical progress. The generalisation of the general theory and other essays. London: Macmillan, 1979.

6 ROBINSON, J. A model of technical progress. Essays in the theory of economic growth. London: Macmillan, 1962. 
A análise de uma economia em que se verifica progresso técnico não pode ser feita com precisão e realismo. Nada existe na realidade que se mantenha constante através do tempo, fornecendo-nos unidades precisas para nossos cálculos. Os trabalhadores adquirem novas aptidôes e perdem as antigas. Os produtos mudam suas características fisicas, sua facilidade de venda e sua capacidade de satisfazer necessidades. As próprias necessidades se modificam junto com os produtos. O poder aquisitivo do dinheiro, com relação às mercadorias, com relação ao tempo de trabalho ou com relação a ambos, muda não só em termos de nível geral como também de padrão. Acima de tudo, os bens de capital se modificam, de forma que os meios de produçāo exigidos para uma técnica mais atual pouco ou nada têm em comum com os antigos. Por outro lado, uma análise que não leve em conta as mudanças técnicas pode ser muito precisa mas de nenhum interesse. (p. 88). 



\title{
THE ACCUMULATION OF CAPITAL
}

\author{
BY \\ JOAN ROBINSON \\ $19<6 a$
}

Third Edition

\author{
MACMILLAN \\ ST MARTIN'S PRESS
}




\section{Chapter 9 \\ TECHNICAL PROGRESS}

WE must now introduce technical progress into the picture. At present we continue to assume that corresponding to each state of technical knowledge there is only one possible method of production for each type of commodity and of equipment (a spectrum of technical possibilities, entailing different ratios of labour to capital in a given phase of knowledge will be discussed in the next chapter). ${ }^{1}$

\section{THE DIFFUSION OF INNOVATIONS}

As time goes by entrepreneurs are continually introducing improvements in methods of production. ${ }^{2}$ Some are more active than others, and in each line there are some progressive firms, who are the first to make innovations, while the rest follow only when compelled to do so by the pressure of competition (those who are obstinately conservative, or who cannot raise funds to make the investments required by new methods are finally driven out of business and their space in the economy is taken up by other men).

The speed at which new methods are diffused throughout the economy depends partly upon the physical life of capital goods. When worn-out equipment is being replaced the new capital goods installed embody the latest devices to which the entrepreneur has access. Innovations which save working capital by speeding up the processes of production are very rapidly diffused (unless kept secret or protected by patents taken out by their first discoverers) for the capital goods

I At this stage we assume that a new method is superior to all older ones at every level of wages.

2 Changes in products are ruled out (see above, p. 66). 
embodied in work in progress are being continuously replaced as production goes on. With durable equipment a continual game of leap-frog is being played. Suppose that ten years is the profitable life of plant in a particular industry; then a nine-year-old plant has the highest costs and yields the lowest profits; next year it is replaced by new plant with all the improvements that have been made over the past ten years. Nine years hence it will again be high-cost plant, having lost its lead gradually as each year's entry of new plant has jumped ahead.

Where equipment has a potentially long life (it is physically durable) the rate at which it is superseded by improved plant depends to a large extent upon the degree of competition between entrepreneurs. A progressive entrepreneur who has installed new plant which reduces the cost of production of a particular commodity may decide to continue selling it at the same price as before, being content with a more or less constant share of the market and enjoying higher profits. In that case unprogressive entrepreneurs are not put under any pressure to become progressive, old plant is no less profitable than before and will live out its natural life, being replaced (if the new methods are accessible) by the improved plant at the time when it would in any case have been due for renewal.

When the progressive entrepreneur prefers to take advantage of lower costs to expand his share of the markets that he serves (or fears that if he does not expand, others will) he cuts prices somewhat to attract customers and raises wage rates to get more labour. To defend themselves entrepreneurs with old plant competing with him have to follow suit, and this goes on until the wage rate in terms of the particular product has risen to the point when old plant no longer yields quasi-rent. Then the old plant is scrapped, and the entrepreneurs concerned either yield their place in the market to the progressive firm or install new plant to hold their own. The leap-frog game is then speeded up, and the economic life of plant is shorter than its potential physical life.

When the speed of diffusion of innovations is very rapid, progressive entrepreneurs get little benefit from their progressiveness, for the excess profits due to having lower costs are rapidly competed away by imitators. An entrepreneur 
who has a new idea which requires to be embodied in a heavy investment in equipment is on the horns of a dilemma. He does not want to install it unless he can be sure of recovering from it enough quasi-rent to amortise the investment and yield at least the ruling rate of profit. If other entrepreneurs will soon be installing even better plant the high-yielding period of this plant will be short, and its total quasi-rent over its life inadequate. But if he does not install it, and his competitors make some equivalent improvement, he will suffer a fall of prices without having enjoyed the reduction of costs. He would prefer no one to make the improvement, but if anyone is to make it he would prefer it to be himself. This leads to what we may call the paradox of patents. A patent is a device to prevent the diffusion of new methods before the original investor has recovered profit adequate to induce the requisite investment. The justification of the patent system is that by slowing down the diffusion of technical progress it ensures that there will be more progress to diffuse. The patent system introduces some of the greatest of the complexities in the capitalist rules of the game and leads to many anomalies. Since it is rooted in a contradiction, there can be no such thing as an ideally beneficial patent system, and it is bound to produce negative results in particular instances, impeding progress unnecessarily, even if its general effect is favourable on balance. In many lines of production legal patents are unimportant and the same essential paradox shows itself rather in the jealous guarding of 'know how' by the progressive firms.

\section{THE CONDITIONS FOR STABILITY}

An increase in output per head at an even pace equal in all lines of production is equivalent, from the point of view of potential output, to an increase in the labour force at the corresponding rate. To simplify exposition we will assume that the population is constant, so that we can confine the analysis to an increase in potential output coming only from increasing productivity. Now, when the system is working in such a way that productive capacity increases at the same pace as output per head, there is steady employment of the 
given labour force over the long run. The division of the labour force (and of productive capacity of capital goods) between the investment sector and the consumption sector then remains unchanged as time goes by. A given number of workers in the investment sector produce plant (for both sectors) of an ever increasing productive capacity, and a given number of workers in the consumption sector operate it to produce an ever increasing output. Real wages rise with output per man, and the rate of profit remains constant.

As the standard of life of the workers rises, hours of work may be falling, or the amount of labour provided by a given population may be reduced by a rise in the age of entry into industry, a fall in the age of retirement, or less employment of women. This does not disturb the smooth development of the economy, provided that it affects both sectors equally. It merely means that total output rises less fast than output per man-hour, ${ }^{\mathrm{I}}$ and that workers are receiving part of the benefit of increasing productivity in the form of leisure instead of commodities.

When productivity alters, the relations between the values of money, labour, commodities and capital goods are changed. When the real wage rises with output per head (and the rise in output per head is evenly distributed through the economy) ${ }^{2}$ the cost of capital goods in terms of commodities is constant. The money-price level then depends upon the money-wage level. For instance, if money wages are constant, the money price of commodities falls as output per head rises, and so does the cost of machines. If money wages rise with outpur per head money prices are constant. When we introduce rentiers into the model, changes in the money prices of commodities will assume great importance. Meanwhile they need not concern us. The prices which are important for this layer of the analysis are the cost of labour in terms of commodities - that is the real wage per man-hour - and the cost of machines in terms of commodities, which is governed by the

I It must be observed, however, that with single-shift working, a shorter day reduces the productive capacity of given plant, and increases the ratio of capital to labour with a given technique of production. This point is discussed below, p. I70.

2 And the time pattern of the processes of production is unchanged. 
real-wage rate and the productivity of labour in the investment sector.

The first essential condition for smooth development of a progressive economy is that the stock of machines (in terms of productive capacity) ${ }^{I}$ is growing at the rate appropriate to the increase in output per man that is taking place, while competition ensures that prices move relatively to money-wage rates in such a way as to keep equipment working at normal capacity, that is, in such a way as to cause the level of real wages to rise with output per man, so that sufficient demand always exists to absorb the ever-growing output of the evergrowing stock of equipment.

Secondly, to preserve a stable level of employment it is necessary that any chance discrepancy between available labour and equipment should be quickly eliminated. This occurs provided that when there is surplus labour the real-wage rate rises less fast than output per head but at the same time outlay on the investment sector is maintained in such a way that accumulation in terms of productive capacity is speeded up in the manner discussed in the last chapter. When there is scarcity of labour money wages rise relatively to prices, the real wage rises by more than output per man and the rate of accumulation is slowed down. When this mechanism is operating the supply of capital goods is continuously adjusted to the supply of labour, and any tendency to surplus or scarcity of labour is promptly corrected.

It is only necessary to set out the conditions required for stability to see how precarious the preservation of stability is under the capitalist rules of the game. In what follows we will discuss situations in which the conditions break down because : (I) the rate of technical progress alters unexpectedly ; (2) the competitive mechanism becomes clogged; (3) accumulation tends to vary relatively to the rate of increase of productivity; (4) technical progress fails to be spread evenly throughout the system.

1 For the time being we assume that increasing productivity is brought about without requiring any change in the time pattern of the processes of production. A more general treatment of technical progress must be deferred until we have discussed the problem of measuring capital. 


\section{THE PACE OF PROGRESS}

The more rapid is the rise of output per head due to technical progress the faster will real wages rise (with a given amount of employment), but the more rapid is the rate of technical progress which the economy has come to expect, the lower is the level of real wages at any moment. This proposition can be unravelled by means of another comparison between Beth and Alaph. The labour forces in the two economies are alike and at the moment when the comparison is made they are in the same phase of technical development. It has been reached in Alaph by a longer and slower process, and the Alaph entrepreneurs expect a slower rate of development in the future than those in Beth ; they are carrying on a smaller rate of investment.

Since the rate of accumulation is higher in Beth, a larger part of the labour force (with appropriate equipment) is occupied in producing replacements and a smaller proportion engaged on producing consumption goods. Real wages are lower in Beth. In money terms, if the money-wage rate is the same in each, the price level is higher in Beth, and entrepreneurs there recover the initial cost of plant out of quasi-rent over a shorter period.

If full employment is maintained, the real-wage rate in Beth will rise more rapidly as time goes by and sooner or later it will surpass the level in Alaph.

It does not follow that if the pace of innovation in one economy changed to that of the other, the difference between them would quickly disappear, for the situation in each is moulded by a long past history.

Let us suppose that in Beth the rate at which innovations are being introduced falls to the pace obtaining in Alaph (whether because inventiveness dries up or because competitive pressure slackens and the rate of diffusion of inventions slows down). The immediate effect is that entrepreneurs with old-fashioned plants are pleasantly surprised to find that they are still earning after the date when it was expected that they would have to be scrapped. But if, as a result of this, orders for replacements fail to be made there is 
unemployment in the investment sector. Consequently there is unemployment also in the consumption sector and slump conditions prevail. The economy may take a long while to recover from this shock and it may sink into a long period of stagnation.

Contrariwise, if the pace speeds up in Alaph to the original Beth rate, some capital goods have to be scrapped before their initial cost has been fully recovered. The entrepreneurs who have installed new low-cost plant find that there are expanding potential markets at a level of prices just below the least that the high-cost producers will accept, and they set about expanding their productive capacity to take advantage of the situation. There is a rush to invest, which draws labour out of the consumption sector and causes real wages to fall. If the workers in Alaph are strongly organised they may set up an inflation barrier at the level of real wages to which they have become accustomed, so that the attempt to increase investment is frustrated. The entrepreneurs then make speeches to the workers pointing out their short-sighted folly - if only they would permit real wages to be reduced for a time they will rise far higher in the future. But lectures may not be sufficient to check inflation.

In each case there is a path which it is possible for the economy to follow to a new line of smooth development. Suppose that in Beth the entrepreneurs who find themselves with redundant amortisation funds promptly set about in esting them in more equipment of the type already in use. A condition of scarcity of labour then develops (assuming that there was more or less full employment in the first instance) the real-wage rate rises and the rate of accumulation is slowed down in the manner that we have already analysed. When the wage and the rate of accumulation strike the level obtaining in Alaph (and the stock of capital goods has been appropriately adjusted) the Beth economy can proceed along the Alaph line without further perturbations.

In Alaph, when the rate of progress speeds up, the level of real wages would be held constant if labour from the consumption sector were drawn off just at the (now faster) pace at which output per man is rising, until the proportion af 
labour (with appropriate equipment) in the investment sector was raised to the original Beth ratio. From then on, Alaph can follow the Beth path from the point that Beth would have reached when wages there had just caught up with the Alaph level.

In each case such a gradual transition to a changed pace of progress is technically possible, but there is no mechanism provided by the capitalist rules of the game that can be relied upon to steer the economy on to the appropriate course. A prolonged slump in Beth and a sharp boom in Alaph are much more probable than a smooth adaptation to the change in the pace of technical progress, and each would have disturbing consequences for a long time after it occurred.

\section{UNDER-CONSUMPTION}

The mechanism which ensures that actual output expands more or less in step with the rise in potential output due to technical progress is the competition which keeps prices in line with costs, and so raises the real-wage rate with productivity. This mechanism tends to grow weaker as the economy progresses, for the more vigorous is competition between entrepreneurs the more rapidly do the strong swallow up the weak, so that the number of separate sellers in each market tends to fall as time goes by. ${ }^{\mathrm{I}}$

Let us consider an extreme case of atrophy of the competitive mechanism. Money-wage rates are constant, and prices have ceased to fall with costs ; in so far as competition is still going on, it takes the form of advertising and salesmanship. (We assume for simplicity that advertising employs a negligible amount of labour, so that advertisers are, in effect, taking a share of the profits of productive entrepreneurs.) Once competition in selling has taken root, entrepreneurs whose production costs are falling (as output per man rises, with constant wages) find that they need increasing margins to cover

I At the same time fresh opportunities are created for 'small men' in specialised chinks of markets and in the interstices between the giants, but this does little to keep competition alive, for the small men find it more profitable to operate in the shelter of the giants' price policy than to stir up trouble by challenging them to competition. 
increasing selling costs, so that (even without overt monopolistic agreements) price-cutting seems to be out of the question.

Now, if the real-wage rate is constant the total volume of output of commodities is constant. If, in the first instance, money outlay on the investment sector is maintained, productive capacity tends to increase at a rising rate, for machines of a given productive capacity are falling in cost as output per head rises in the investment sector. But with a constant output of commodities there is no use for more machines. (The under-utilisation of plant fails to bring down prices because of the atrophy of competition.) Moreover, employment in both sectors is falling as output per man rises, and consequently the sales of commodities and the outlet for investment are not only failing to expand, but actually shrinking. The whole process goes on slowly, for in these conditions the diffusion of innovations is sluggish (output per head may be rising at, say, less than one per cent per annum) and the strongest entrepreneurs may still be making profits, which they invest in buying up the businesses of weaker colleagues, so that no one notices that total output is shrinking and the situation does not present itself to the entrepreneurs as a crisis until the gradually increasing volume of unemployment creates a political problem for them.

The socialist writers of a hundred years ago ${ }^{1}$ who proclaimed that this extreme form of under-consumption (due to the constancy of the real-wage rate) was an inescapable consequence of the capitalist rules of the game were evidently exaggerating, but in a mild form it is an ever present menace to the prosperity of a technically progressive economy (all the more so to-day when a kind of remedy has been found in accumulating armaments instead of productive capital).

When it is present in only a mild form, so that real-wage rates are rising somewhat, though less than enough to keep the economy at stretch, the corrective of reducing hours of work may come into operation. When wages per man-hour are rising, but jobs growing harder to find, the workers may succeed in obtaining a reduction of hours of work without a

I E.g. Sismondi, Nouveaux principes d'économie politique. 
reduction of real income per family, thus turning unemployment into leisure and improving their standard of life without increasing physical consumption. This keeps the growth of unemployment within bounds and an appearance of harmony is preserved in the stagnant economy.

The main defence against the tendency to stagnation comes from pressure by trade unions to raise money-wage rates. When they succeed, the stickiness of prices tells in their favour, for entrepreneurs may prefer (within limits) to accept a cut in margins rather than to alter their price policy. In so far as this occurs, real-wage rates rise. If by this means real wages can be made to rise as fast as output per man the root of the trouble is cut, and the economy can accumulate capital and increase total product at the rate appropriate to the pace at which technical improvements are being introduced, just as though competition were still active.

It may then happen that the most progressive entrepreneurs become the allies of the trade unions for, even with rising wages, their costs are lower than those of their competitors, and the rise in wages speeds up the rate at which high-cost producers are squeezed out of existence. Self-interest, humanitarianism and political savoir-faire join in generating the philosophy of 'the economy of high wages', and the trade unions, in turn, may become the allies of the progressive monopolists. A kind of live-and-let-live system is then established, and provided that real wages are rising somewhat (over the long run) no one is concerned to inquire if they might be made to rise faster by a more rapid rate of accumulation.

\section{ACCUMULATION AND TECHNICAL PROGRESS}

Accumulation weak. When the rate of accumulation fails to keep productive capacity expanding as fast as output per man-hour is rising, employment in terms of man-hours of work is falling. Harmony may still be preserved if hours of work are being reduced at the same time (by shortening the working week, or the working lifetime). Where this relief is not operating (or is operating too weakly), increasing output per man reduces the number of men employed (population 
CHAP. 9]

being constant). This is commonly called technological unemployment, for on the surface it appears to be the direct consequence of the increase in productivity which is taking place, but in essence it is of the same nature as the unemployment which follows from a failure of accumulation to keep pace with an increase in population.

The appearance of surplus labour checks the rise of real wages, which causes surplus capacity to appear in the consumption sector. This further weakens the pressure to accumulate and generates all the more unemployment and surplus capacity. But technical progress, at the same time, itself tends to be slowed down. With growing unemployment the workers develop a Luddite resistance to increasing productivity, and, with hands always available, the entrepreneurs have little motive for bothering about introducing improvements. In short, when accumulation tends to be slower than the rate which technical progress makes possible, growing unemployment tends to pull it down; at the same time the weight of its own sluggishness drags back the rate of technical progress.

Accumulation strong. 'l'he same mechanism works on the opposite tack, when accumulation is running ahead of technical progress.

With a given labour force and given technique, an upper limit is set to the possible rate of accumulation at any moment by the inflation barrier. When technical progress is going on and the competitive mechanism is working, the real-wage rate is tending to rise as time goes by. The inflation barrier is then moving outwards like the horizon of a traveller, for it is a fall in real wages below what they have been in the past rather than below what they might be in the present that brings it into operation. Consequently it is possible for the rate of accumulation (in terms of the growth of productive capacity) to rise progressively (the falling tendency of real wages due to an increasing rate of accumulation pressing against the rising tendency due to technical progress, without outweighing it). Thus it is possible for the rate of accumulation to accelerate up to a certain point (provided that entrepreneurs are sufficiently active to make it do so) without encountering the inflation barrier. 
But accumulation cannot permanently continue (with a given labour force) at a faster rate than technical progress. When it has been faster for a time a condition of scarcity of labour begins to emerge, as the increment of new capital goods requiring man-power grows from month to month, just as it does when accumulation is running ahead of the growth of population with constant technique. (All the more so if the supply of labour per family is falling as working hours per lifetime are reduced.) Real wages tend to rise faster than output per head, the rate of profit tends to fall, and the increased demand for consumption goods tends to draw labour out of the investment sector, so that the rate of accumulation tends to be slowed down to the pace of technical progress.

But at the same time technical progress is being speeded up to keep step with accumulation. The rate of progress is not a natural phenomenon that falls like the gentle rain from heaven. When there is an economic motive for raising output per man the entrepreneurs seek out inventions and improvements. Even more important than speeding up discoveries is the speeding up of the rate at which innovations are diffused. When entrepreneurs find themselves in a situation where potential markets are expanding but labour hard to find, they have every motive to increase productivity; and the experience of wage rates rising with output overcomes the reluctance of the workers to assist them to do so.

In short, the capitalist rules of the game produce the most flourishing results when the available supply of labour is tending to shrink ${ }^{\text {I }}$ (population is increasing little, if at all, and hours of work are falling) and the available supply of capital tending to grow, so that a rise in real wages (due to scarcity of labour) is constantly threatening a fall in the rate of profit, which technical progress is constantly fending off. In these conditions the economy is most highly productive (though not necessarily most agreeable in other ways).

1 According to the basic assumptions of our model, the labour force is in any case large enough to ensure constant returns, that is to say, there are no economies of large-scale total production which lead to an increase of output per head merely because total output is increasing. This question is discussed below, Chapter 33 . 


\section{BIASED TECHNICAL PROGRESS}

So far we have assumed technical progress to be evenly distributed throughout the economy. How does the system develop when one sector is more strongly affected than the other? Let us first examine the situation when inventions and discoveries have been fully digested into the stock of capital. In Beth and Alaph the labour forces are alike; and the rate of output of commodities, the real-wage rate and the rate of profit on capital are all the same in each. The only difference between the two economies is that, owing to a bias in technical progress in the past, Alaph has a higher rate of output of commodities per man in the consumption sector and a lower rate in the investment sector, reckoning output in the investment sector in terms of machines of given productive capacity. A larger proportion of the labour force is employed in the investment sector in Alaph than in Beth and the cost of machines (of given capacity) in terms of commodities is higher. Looking at the situation from the point of view of a worker in the consumption sector, his output is higher in Alaph, but he has to part with a larger proportion of his output to get himself provided with equipment. From the point of view of an entrepreneur, quasi-rent per man employed in the consumption sector is higher (for output per man is higher and the real wage the same) but the cost of the outfit of capital goods per man employed is correspondingly higher, and the rate of profit is the same. ${ }^{I}$ The technique of production in Alaph may be said to have a capital-using bias, compared to that in Beth, or the technique in Beth a capital-saving bias compared to that in Alaph.

Now let us suppose that technical progress in an economy takes on a capital-using bias - that is to say, innovations are

1 For example, suppose that in each economy stationary conditions obtain, with zero profits. In each, 100 teams of men are employed, 100 units of commodities and 5 outfits of machines (of given capacity) are produced per annum. The stock of machines in use consists of 40 outfits in the consumption sector and 10 in the investment sector. ro per cent of machines are replaced every year. In Beth, 80 teams are employed in the consumption sector and 20 in the investment sector. In Alaph, 75 and 25 . In Beth, 4 outfits of machines are sold by the investment sector to the 
made which raise output per man-hour faster than before in the consumption sector and more slowly in the investment sector. For simplicity we will suppose that for a time there are no improvements at all in the investment sector, so that a constant amount of labour is required to produce a machine of given productive capacity while a bout of inventions occurs in the consumption sector. The immediate effect of the innovations that are now introduced is a fall in employment in the consumption sector, for initially new productive capacity is coming forward at the same rate as before, while each new outfit of machines that comes into use in the consumption sector requires less labour to man it than that which it replaces. Unemployment checks the rise in real wages, but at the same time it is possible for the rate of accumulation to be speeded up. If this happens, at least some part of the labour expelled from the consumption sector finds employment in the investment sector. The real-wage rate has risen (if at all) less than output per head in the consumption sector, and the rate of profit for the time being is higher than before. The situation presents itself to the entrepreneurs as an investment boom, though it took its origin in an outbreak of unemployment. After a time the stock of equipment becomes adjusted to the new technical situation and (if no further disturbances occur) the rate of accumulation and the rate of profit may return to their former level.

Conversely, if a bout of inventions are made which raise output per man in the investment sector, while leaving it unchanged in the consumption sector, the rate of increase of productive capacity is temporarily speeded up; scarcity of labour develops in the consumption sector, the real-wage rate rises (while output per head in that sector is constant) and the

consumption sector for 20 units of commodities (the wages bill of the investment sector). The value of an outfit of new machinery is therefore 5 units of commodities, and the value (neglecting interest) of the park of 50 outfits of machines of balanced age composition is $\frac{1}{2}(50 \times 5)=125$. In Alaph 4 outfits are sold for 25 units of commodities and the value of the park is $\frac{1}{2}(50 \times 61)=156 \frac{1}{4}$. Quasi-rent (in terms of commodities) per outfit of machines in the consumption sector is $\frac{1}{2}$ in Beth and $\frac{5}{8}$ in Alaph. In the investment sector the quasi-rent on ro outfits of machines is one outfit, which is worth 5 units of commodities in Beth and $6 \frac{1}{1}$ in Alaph. 
rate of profit falls, until sufficient labour has been drawn out of the investment sector into the consumption sector to restore the balance.

\section{THE GOLDEN AGE}

When technical progress is neutral, and proceeding steadily, without any change in the time pattern of production, the competitive mechanism working freely, population growing (if at all) at a steady rate and accumulation going on fast enough to supply productive capacity for all available labour, the rate of profit tends to be constant and the level of real wages to rise with output per man. There are then no internal contradictions in the system. Provided that political events cause no disturbances, and provided that the entrepreneurs have faith in the future and desire to accumulate at the same proportional rate as they have been doing over the past, there is no impediment to prevent them from continuing to do so. As long as they do, the system develops smoothly without perturbations. Total annual output and the stock of capital (valued in terms of commodities) then grow together at a constant proportionate rate compounded of the rate of increase of the labour force and the rate of increase of output per man. We may describe these conditions as a golden age (thus indicating that it represents a mythical state of affairs not likely to obtain in any actual economy).

If we conceive the rate of technical progress and the rate of growth of population as given by nature then we may say that the golden age appropriate to the given conditions represents a state of economic bliss, since consumption is then increasing at the maximum technically feasible rate which is compatible with maintaining that rate of increase. ${ }^{I}$ But this is not a very enlightening way of looking at the matter, for technical progress is not a natural phenomenon, and there is no limit to human ingenuity. Whatever rate of progress is being maintained, in a golden age, it would always be possible to progress faster. If the rate of accumulation were speeded

1 In the language of Mr. Harrod's Towards a Dynamic Economy the natural, the warranted and the actual rate of growth of national income are all equal. 
up (or the rate of growth of population were to decline, or the available supply of labour to be reduced by shortening hours, while accumulation went on as fast) the pressure of scarcity of labour, driving up wage rates, would induce more inventions to be made and hasten the diffusion of improvements already known, so that the level of real wages would rise all the faster. The limit to the rate of growth of wealth, over the long run, is set not by technical boundaries but by the lethargy which develops when the goad of competition and rising wage rates is blunted. 
